Snežana Z. Detar Jevđović *

https://doi.org/10.18485/analiff.2018.30.1.8

Osnovna škola „Petar Petrović Njegoš“

Beograd
$811.131 .1 ' 243$

Originalni naučni rad

Primljen: 23.04.2018.

Prihvaćen: 15.07.2018.

\title{
LEKSIČKI I MORFOLOŠKI TRANSFER U POČETNOJ NASTAVI ITALIJANSKOG JEZIKA KAO STRANOG
}

\begin{abstract}
U radu se pored teorijskog okvira, iznose rezultati istraživanja koje ispituje na koji način nivo znanja i količina izloženosti engleskog kao prvog stranog jezika utiču na pisanu produkciju leksike i morfologije italijanskog kao drugog stranog jezika kod učenika u početnoj nastavi italijanskog jezika kao stranog. Testirani su učenici petog razreda osnovne škole „Petar Petrović Njegoš” koji uče engleski jezik od prvog i italijanski od petog razreda. Dobijeni podaci obrađeni su metodama kvantitativne i kvalitativne analize. Glavni cilj rada usmeren je na kritičku analizu leksičkih i morfoloških oblika međujezika učenika petog razreda. Rezultati istraživanja su pokazali da dve vrste međujezičkog transfera dominiraju prilikom građenja ciljnih reči u pisanoj produkciji na italijanskom jeziku učenika petog razreda: 1. leksički međujezički transfer koji se odnosi na upotrebu cele neciljne reči (iz engleskog jezika) u produkciji ciljne reči (u italijanskom jeziku) i 2. morfološki međujezički transfer koji se odnosi na produkciju oblika međujezika kod koga se slobodna ili vezana morfema iz engleskog jezika kombinuje sa slobodnom ili vezanom morfemom iz italijanskog jezika u cilju nastajanja reči slične onoj u ciljnom jeziku.
\end{abstract}

Ključne reči: međujezički transfer, nivo znanja, količina izloženosti, leksika, morfologija, engleski i italijanski jezik, prvi i drugi strani jezik

\section{Uvod}

Predmet ovog rada jeste ispitivanje uticaja engleskog kao prvog stranog jezika na učenje italijanskog kao drugog stranog jezika u kontekstu formalnog obrazovanja u Srbiji. U radu se analizira uticaj varijabli 1. nivo znanja engleskog jezika i 2. količina izloženosti engleskom jeziku

Resavska 61, Beograd, biancaneve301@hotmail.com. 
na pojavu međujezičkog transfera kod učenika petog razreda tj. prve godine učenja italijanskog jezika. Cilj istraživanja usmeren je na izdvajanje i određivanje konstrukcija karakterističnih za međujezik učenika na polju leksike i morfologije na osnovu kojeg se određuje da li engleski jezik ima veći uticaj kod onih ispitanika koji poseduju viši nivo znanja engleskog jezika i koji su u većoj meri bili njemu izloženi. Zatim, da li se transfer može uočiti i kod onih ispitanika koji poseduju nizak nivo znanja i koji su slabo bili izloženi engleskom jeziku. U istraživanju se pošlo od pretpostavke da varijable nivo znanja i količina izloženosti utiču na pojavu međujezičkog transfera, kao i da je međujezički transfer veći na polju leksike i morfologije kod onih ispitanika koji poseduju viši nivo znanja engleskog jezika i koji su u većoj meri bili njemu izloženi.

U prvom delu rada iznet je teorijski okvir sprovedenog istraživanja koji se odnosi na međujezički transfer. Osim definisanja samog pojma posebno su opisane varijable nivo znanja jezika i količina izloženosti kao faktori koji dovode do međujezičkog uticaja. Takođe, u ovom delu rada su prikazani i leksički i morfološki transfer budući da je tu međujezički uticaj najevidentniji.

Drugi deo rada posvećen je analizi upitnika za nastavnike i učenike kao i testova nivoa znanja engleskog i italijanskog jezika učenika petog razreda. Ovaj deo istraživanja daje sliku konteksta u kome se uči engleski jezik ispitujući varijable nivo znanja i količinu izloženosti. Pored toga prikazani su i analizirani rezultati testiranja u vezi sa pisanom produkcijom na italijanskom jeziku učenika petog razreda. Na osnovu rezultata gorenavedenih testova izdvojeni su i analizirani oblici međujezičkog transfera u okviru leksike i morfologije. Takođe, ovaj deo rada obuhvata i poređenje rezultata celokupnog testiranja pisane produkcije na italijanskom jeziku učenika petog razreda.

U zaključku rada predstavljeni su rezultati istraživanja koji su sagledani u okviru definisanih ciljeva i pretpostavki.

\section{Međujezički transfer}

Iako je fenomen međujezičkog transfera već dugo vremena predmet istraživanja, naučnici nailaze na teškoće prilikom usaglašavanja mišljenja o procesima koji omogućavaju njegovu pojavu.

Odlinova (1989) definicija transfera se često citira budući da je dovoljno sveobuhvatna i zastupa različita gledišta. Transfer predstavlja uticaj 
LEKSIČKI I MORFOLOŠKI TRANSFER U POČETNOJ NASTAVI ITALIJANSKOG ...

koji nastaje kao rezultat sličnosti i razlika između ciljnog i bilo kog drugog jezika koga je učenik prethodno (i verovatno nedovoljno) učio (Odlin, 1989: 27). U okviru ove definicije, Odlin uključuje kako pozitivni transfer, tako i pojavu negativnog transfera kao što su nedovoljna ili preterana produkcija određene jezičke konstrukcije; greške u produkciji kao što su zamena jezika, kalkovi, adaptacije u ciljnom jeziku, pogrešne interpretacije $\mathrm{u}$ razumevanju, i takođe, razlike u količini vremena potrebne učeniku sa različitim jezičkim iskustvom da nauči ciljni jezik (Murphy, 2003).

\section{Faktori koji utiču na međujezički transfer}

Rana istraživanja u okviru multilingvizma ističu jezičku ili tipološku bliskost među jezicima kao glavni faktor transfera (Ringbom, 1987). Ona navode da ukoliko su jezici koji se uče tipološki slični, onda postoje olakšavajući faktori prilikom učenja (pozitivan transfer). Međutim, kada postoji divergencija između jezika, do međujezičkog transfera može doći u obliku grešaka, preterane ili sa druge strane nedovoljne produkcije, kao i pogrešnog razumevanja (negativni transfer) (Odlin, 1989).

Kompleksnost međujezičkog uticaja, kako je prikazano u gorenavedenom pregledu literature, ukazuje da je mnogo faktora uključeno i u interakciji je kada jezici dolaze u kontakt. Stoga, kasnija istraživanja (De Angelis and Selinker, 2001; Dewaele, 1998; Ringbom, 2001) ističu i druge faktore kao što su: nivo znanja, količina izloženosti, upotreba jezika tj. učestalost korišćenja, redosled usvajanja, status jezika, kontekst kao najrasprostranjenije faktore međujezičkog transfera.

\subsection{Nivo znanja}

Kada se govori o faktoru nivo znanja jezika neophodno je napomenuti da se u literaturi o međujezičkom faktoru o ovoj varijabli raspravlja u odnosu na nivo znanja ciljnog i izvornog jezika. U pogledu nivoa znanja ciljnog jezika, pojedini autori (Odlin, 1989; Ringbom, 1986; Poulisse \& Bongaerts, 1994) zastupaju mišljenje da će do međujezičkog transfera doći verovatnije u ranim fazama učenja, kada je znanje ciljnog jezika nedovoljno i fragmentarno, a potreba da se popune praznine velika. U pi- 
tanju je vrsta strategije koju učenici primenjuju kada im nedostaju jezička sredstva izažavanja u ciljnom jeziku.

Pojedini autori (Poulisse \& Bongaerts, 1994) se u svom radu posebno bave analizom jezika. U vezi sa tim, prave korelaciju između niskog znanja ciljnog jezika i transfera koju objašnjavaju pretpostavkom da su morfeme iz izvornog jezika jako aktivne kod učenika na početku učenja zbog svoje visoke učestalosti te se stoga lako selektuju u toku jezičke produkcije (Poulisse \& Bongaerts, 1994). Odlin (1989) u svom radu primećuje da je u ranim fazama učenja, transfer često negativan budući da nastaje kao rezultat strategije da se popune praznine u znanju ciljnog jezika. S druge strane, na rezultate pozitivnog transfera se obično nailazi u kasnijim fazama učenja, kada se učenici češće pomažu znanjem drugih jezika, a posebno poznatim vokabularom (De Angelis, 2007).

U prvim svojim radovima, Ringbom (1987) ističe da nivo znanja izvornog jezika određuje tip transfera u ciljnom jeziku. Nastojeći da napravi razliku između transfera oblika i značenja, ${ }^{1}$ zastupa ideju da je transfer oblika relativno površan tip transfera. Navodi da se on podjednako tiče i maternjeg i prvog stranog jezika budući da nivo znanja ne utiče na pojavu ovog tipa transfera. Međutim, kada govori o transferu značenja Ringbom smatra da do njega može doći samo sa jezika koje govornik dobro poznaje, stoga sa maternjeg ili prvog stranog jezika u kojima je govornik veoma fluentan (De Angelis, 2007). Kasnije, u radovima iz 2001. Ringbom zastupa tezu da prvi strani jezik pruža više materijala za transfer oblika. S druge strane, navodi da primeri transfera značenja kao i semantički zasnovanog leksičkog transfera, koji zahtevaju značajnu fluentnost i automatizaciju izvornog jezika, pružaju više dokaza o uticaju maternjeg na drugi strani jezik (Ringbom, 2001).

$U$ vezi sa međujezičkim transferom u oblasti učenja drugog stranog jezika, Ringbom (1986) primećuje da što manje učenik zna ciljni jezik, više je prisiljen da se osloni na druga prethodna znanja koje poseduje. Međutim, da bi prvi strani jezik pružio materijal za transfer, govornik mora posedovati određeni nivo znanja prvog stranog jezika (Hammarberg, 2001).

Prema nekim autorima (Ringbom, 1987; Agustín Llach, M.P, 2010; De Angelis; 2007) nivo znanja prvog stranog jezika je od velike važnosti

1 Ringbom $(1987,2001)$ pravi razliku između transfera oblika i značenja. Pod transferom oblika Ringbom podrazumeva prebacivanje s jednog jezika na drugi (preključivanje koda), hibridne tvorevine, slivenice i varljive kognate, dok transfer značenja uključuje kalkove i semantičke ekstenzije (v. Pog. 4.1. Leksički transfer). 
pošto će napredni učenik biti u stanju da koristi strategije iz prvog stranog jezika koje se inače pozajmljuju samo iz maternjeg. Stoga se zaključuje da nijedna forma koja postoji u drugom stranom jeziku neće biti pozajmljena iz prvog stranog ukoliko nivo znanja tog jezika nije visok.

Tremblay (2006) u svom radu naglašava da je uticaj prvog stranog jezika negativan osim u slučajevima kada je učenik dostigao visok nivo automatizacije. Međutim, visok nivo znanja prvog stranog jezika nije dovoljan da bi jezik postao automatizovan (Ortega, 2008).

\subsection{Količina izloženosti}

Pojedini autori (Murphy, 2003) nastoje da faktor količina izloženosti stranom jeziku definišu kao dužina boravka u sredini ciljnog jezika ili u slučaju učenika stranog jezika, kao količina stranog jezika kojoj je učenik izložen u školskom ili vanškolskom ambijentu (Murphy, 2003:8). Količina izloženosti stranom jeziku ima jak uticaj na verovatnoću pojave kako pozitivnog tako i negativnog transfera (Odlin, 1989).

\section{Tipovi međujezičkog uticaja}

\subsection{Leksički transfer}

Istraživanja o leksičkom transferu nisu novijeg datuma. Odlin (1989: 7) u svom radu govori o leksičkom transferu kao pojavi koja se već dugo vremena ispituje i navodi da su pozjamljenice tema studija koje datiraju još iz 19. veka. Među drugim oblicima leksičkog transfera Odlin izdvaja neologizme ili adaptacije reči maternjeg jezika fonetskim pravilima prvog stranog jezika; lažne prijatelje, reči istog korena, ali različitog značenja; kao i kalkove ili bukvalne prevode na prvi strani jezik reči iz maternjeg, kao primere negativnog transfera (Odlin, 1989). Ovaj autor smatra da leksički transfer može imati i pozitivna, olakšavajuća dejstva u učenju jezika, u vidu kognata, reči istog korena i uglavnom istog značenja, što navodi kao primer pozitivnog leksičkog transfera (Odlin, 1989:77-79).

Jednu od najopsežnijih studija o međujezičkom transferu je sproveo Ringbom 1987. u Finskoj. On je identifikovao nekoliko oblika međujezičkog transfera stranog jezika koje je uopšteno kategorizovao kao pozajmljenice (u 
koje uključuje i hibridne tvorevine i složenice) i oblike leksičkog transfera (kalkovi, semantičke ekstenzije, kognati i lažni prijatelji).

Baveći se uticajem finskog i švedskog jezika kao prvog stranog na engleski kao drugi strani jezik De Angelis (2007) se poziva se na Ringbomovu klasifikaciju. U skladu sa njom daje primere leksičkog transfera, izdvaja i definiše sledeće oblike međujezika:

1. Kalkovi - slučaj kada se semantička svojstva jedne reči prenose na kombinaciju leksičkih jedinica. Na pr. 'child wagon' za 'pram'(na švedskom barnvagn);

2. Semantičke ekstenzije - slučaj kada se semantička svojstva proširuju na reč iz prvog stranog jezika. Na pr. 'He bit himself in the language' (na finskom kieli = znači i 'tongue' i 'language').

3. Kognati (uključuju i lažne prijatelje) - slučajevi formalne međujezičke sličnosti reči različitih odnosa:

a) u potpunosti različito značenje: 'at the time he works in a fabric' (na švedskom fabric = 'factory');

b) slično, ali identično značenje van konteksta: 'The next day we grounded a club' (na švedskom grunda = 'found');

c) u nekim, ali ne svim kontekstima identično ili skoro identično značenje: ' The hound is the best friend of man' (na švedskom hund $=$ 'dog', povremeno isto 'hound');

4. Hibridne tvorevine i slivenice - slučajevi morfološke ili fonetske modifikacije reči u skladu sa normama prvog stranog jezika. Na pr. 'In the morning I was tired and in the evening I was piggy' (na švedskom pigg='refreshed');

5. Pozajmljenice - slučajevi potpune zamene jezika ili releksifikacije ${ }^{2}$ tj. izostanka modifikacije reči u skladu sa normama prvog stranog jezika. Na pr. 'I'm usually very pigg after the diet' (na švedskom pigg = 'refreshed').

Kao što je već izneto u delu o nivou znanja jezika (v. Poglavlje 3.1.), iz proceduralne perspective leksički transfer se može manifestovati kao transfer oblika i transfer značenja. Ringbom (2001) pravi razliku između prebacivanja s jednog na drugi jezik (preključivanje koda), hibridnih tvorevina, slivenica $i$ varljivih kognata kao tipova transfera forme tvrdeći da oni mogu nastati nezavisno od nivoa znanja jezika. Transfer forme čini

2 Releksifikacija je zamena domaće reči ili izraza stranim. U radu se dati pojam odnosi na zamenu reči drugog stranog jezika originalnom reči ili izrazom iz prvog stranog jezika. 
upotreba reči iz prvog stranog jezika, prilagođenih ili ne ciljnom jeziku u toku produkcije ciljnog jezika (Ringbom, 2001:60). U pogledu transfera značenja Ringbom pravi razliku između kalkova i semantičkih ekstenzija (Ringbom, 2001:60). Ovaj autor smatra da je bez obzira na sličnosti između prvog i drugog stranog jezika, ovaj tip transfera zasnovan na maternjem, a retko kada na prvom stranom jeziku (osim ukoliko je strani jezik maternji jezik). Ringbom $(1987,2001)$ navodi da do transfera značenja može doći samo iz jezika koje govornik dobro poznaje. Ovaj autor objašnjava da transfer kao pojava postaje površan ukoliko nema transfera značenja, te su greške učenika najevidentnije kod oblika pozajmljenica (Ringbom, 1987).

Leksički transfer se javlja kao odgovor na više činilaca. U literaturi o učenju/usvajanju prvog stranog jezika transfer se posmatra kao esencijalni saznajni proces (Agustín Llach, M.P, 2010:4). Učenici uspostavljaju odnos jednakosti između reči maternjeg i ciljnog jezika i na osnovu ovih međujezičkih identifikovanja oni vrše transfer leksičkih jedinica koje smatraju zajedničkim za oba jezika (Ringbom, 2001). Manchón Ruiz (2001) primećuje da su manjak vokabulara stranog jezika, nedovoljno poznavanje reči, neautomatizovano i stoga nedostupno leksičko znanje, ili saznajno previše zahtevan komunikativni zadatak situacije u kojima učenik zamenjuje reči prvog stranog onima iz maternjeg jezika. Potreba da se saopšte ideje dolazi u koliziju sa manjkom leksičkog znanja prvog stranog jezika i da bi se prevazišao ovaj problem, učenici se oslanjaju na maternji jezik tako što umeću reči iz maternjeg u diskurs prvog stranog jezika (Dewaele, 1998). U istraživanjima o međujezičkom transferu (Ringbom, 1986, Agustín Llach, M.P, 2010) ovi mehanizmi su poznati kao komunikacione ili kompenzacione strategije te se logično nameće zaključak da se leksički transfer koristi kao kompenzaciona strategija kako se ne bi odustalo od komunikacije.

\subsection{Morfološki transfer}

U literaturi koja se bavi međujezičkim transferom nailazi se na veliki skepticizam u pogledu mogućnosti pojave transfera vezanih morfema, posebno gramatičkih. Dokazi transfera tvorbenih i gramatičkih morfema iz maternjeg ili stranog jezika su retki, ali empirijski dokazi pokazuju da vezane morfeme nisu tako imune na transfer kako se to mislilo (De Angelis, 2007:54). Sa ovim mišljenjem se slaže i Weinreich (1953: 44) kada navodi da određeni tipovi vezanih morfema mogu da budu predmet trans- 
fera u određenim okolnostima i situacijama kada postoji sličnost obrazaca ili relativno slobodnog i invarijantnog oblika morfeme.

Iako gorenavedena istraživanja potvrđuju da je transfer vezanih morfema, iako moguć, redak u toku učenja prvog stranog jezika, Murphy (2003) zastupa tezu po kojoj on predstavlja bitnu karakteristiku leksičkog transfera u toku produkcije drugog stranog jezika. Ova autorka navodi da mnoge studije o učenju drugog stranog jezika govore o onome što Dewaele (1998: 476) naziva leksički izumi: veoma kompleksni međujezički oblici koji bi mogli da dele leksičke, morfološke i fonološke karakteristike svih jezika koje govornik poznaje (Murphy, 2003: 17).

De Angelis \& Selinker (2001) u svojoj studiji takođe nude primere morfološkog međujezičkog transfera i navode slučajeve u kojima slobodna ili vezana morfema maternjeg ili prvog stranog jezika u kombinaciji sa drugom slobodnom ili vezanom morfemom iz ciljnog jezika formira približnu ciljnu reč (De Angelis \& Selinker, 2001: 43).

Po mišljenju nekih autora postoje različita objašnjenja za pojavu morfološkog transfera (Murphy, 2003: 17). Fuller (1999) tvrdi da ovi složeni oblici predstavljaju nesvesnu strategiju u učenju tokom faze niskog nivoa znanja drugog stranog jezika. Prema ovoj hipotezi učenik popunjava praznine u znanju sa materijalom iz jezika koji poznaje bolje budući da još uvek nije usvojio sve nivoe leksičke strukture. Tom prilikom čak krši ograničenja vezana za prebacivanje morfema u drugi jezik(Murphy, 2003: 17).

Pojedini autori (De Angelis i Selinker, 2001) zastupaju mišljenje da su složeni oblici međujezika posledica preslikavanja veze između korena reči i vezanih morfema u jednom jeziku na one iz drugih jezika u jezičkom sistemu govornika.

\section{Istraživanje}

Istraživanje je sprovedno u drugom polugodištu školske 2014/2015. godini u osnovnoj školi „Petar Petrović Njegoš” u Beogradu. Ciljnu grupu su činili učenici petog razreda (43 ispitanika) kojima je maternji jezik srpski, prvi strani jezik engleski i drugi strani jezik italijanski. Pored ovih ispitanika u istraživanju su učestvovala i dva nastavnika, od kojih je jedan držao nastavu engleskog a drugi italijanskog jezika. 


\subsection{Metode, tehnike i instrumenti istraživanja}

Za potrebe istraživanja primenjena je kombinovana metoda koja uključuje neke aspekte kvalitativne i kvanititativne metode. Kada je reč o sagledavanju konteksta nastave engleskog jezika upotrebljena je kvalitativna metoda dok sa druge strane za poređenje i analizu rezultata anketiranja i testiranja ispitanika primenjena je kvantitativna metoda.

Od tehnika rada primenjeno je anketiranje predmetnog nastavnika engleskog i učenika, kao i testiranje učenika u vezi sa pomenutim predmetom istraživanja.

Za instrumente istraživanja upotrebljeni su upitnici za anketiranje nastavnika i učenika i testovi za proveru nivoa znanja engleskog jezika, kao i testovi za proveru pisane produkcije italijanskog jezika.

Upitnik za nastavnika sadrži pored ličnih podata i podatke u vezi sa strukturom časova, sredstvima koje koristi u nastavi, upotrebom stranog i maternjeg jezika u nastavi, kao i kriterijumima pri ocenjivanju učenika.

U upitniku za učenike su sadržane uvodne napomene i sledeće informacije: lični podaci, upotreba i učestalost korišćenja engleskog jezika u školi i van nje, kao i ocena na poslednjem polugodištu iz engleskog jezika.

Cilj ovako koncipiranih upitnika jeje bio da se na osnovu analize odgovora stekne uvid u kontekst učenja engleskog jezika u školi i van nje, kao i da se uporede odgovori učenika petog razreda.

Testovi za proveru nivoa znanja engleskog jezika sadrže vežbanja, aktivnosti i tehnike poput onih koji se mogu sresti u udžbeniku koji se koriste u nastavi (v. Poglavlje 5.3.1). Dobijeni rezultati poslužili su da se izvrši naknadna podela ispitanika na podgrupe: onih sa višim nivoom znanja (ocenjeni sa 5 i 4) i onih sa nižim nivoom znanja (ocenjeni sa 2 i 3 ).

Za testiranje pisane produkcije italijanskog kao drugog stranog jezika za peti razred korišćene su dve vrste testa. Prvi test se zasniva na opisu slike sobe i uključuje poznatu leksiku i strukture rađene na časovima engleskog i italijanskog jezika. Drugi test je podrazumevao pisanje kratkog sastava (sastav je vođen, a instrukcije su date na maternjem jeziku na temu ličnog predstavljanja o čemu je već bilo reči na časovima engleskog i italijanskog jezika). Namera je bila da se na osnovu analize grešaka koju učenici prave uradi analiza oblika transfera u okviru leksike i morfologije tj. da se izdvoje i izbroje jezičke konstrukcije međujezika. 


\subsection{Ciljevi istraživanja i pretpostavke}

$\mathrm{U}$ istraživanju se pošlo od pretpostavke da varijable nivo znanja i količina izloženosti utiču na pojavu međujezičkog transfera, kao i da je međujezički transfer veći na polju leksike i morfologije kod onih ispitanika koji poseduju viši nivo znanja engleskog jezika i koji su u većoj meri bili njemu izloženi.

Cilj ovog segmenta istraživanja je analiza uticaja varijabli 1. nivo znanja engleskog jezika i 2. količina izloženosti engleskom jeziku na pojavu međujezičkog transfera kod učenika petog razreda tj. prve godine učenja italijanskog jezika. Posebna pažnja je usmerena na izdvajanje i određivanje konstrukcija karakterističnih za međujezik učenika na polju leksike i morfologije na osnovu kojih bi se utvrdilo da li engleski jezik ima veći uticaj kod onih ispitanika koji poseduju viši nivo znanja engleskog jezika i koji su u većoj meri bili njemu izloženi. Zatim, da li se transfer može uočiti i kod onih ispitanika koji poseduju nizak nivo znanja i koji su slabo bili izloženi engleskom jeziku.

\subsection{Analiza upitnika za nastavnike i učenike petog razreda}

\subsubsection{Količina izloženosti engleskom jeziku}

Podaci vezani za količinu izloženosti engleskom jeziku su utvrđeni uzimajući u obzir nastavni i vannastvani imput.

Nastavni imput čini celokupan materijal koji je korišćen u nastavi engleskog jezika: udžbenički komplet, kao i dodatni materijal koji donosi predmetni nastavnik. Na osnovu podataka dobijenih u anketnom istraživanju za nastavnika saznaje se da se u nastavi engleskog jezika za peti razred kao osnovno sredstvo koristi udžbenički komplet Project 2 (Third edition).

Nastavnik engleskog jezika je u upitniku naveo da na svojim časovima ponekad koristi dodatni materijal. Objašnjava da su uglavnom u pitanju slike koje služe da bi se uvežbalo opisivanje istih i razvijale govorne veštine. Takođe, $\mathrm{u}$ radu koristi tekstove stranih popularnih pesama u cilju uvežbavanja gramatičkih konstrukcija ili poznatih reči, kao i ludičke aktivnosti poput kvizova koje sama priprema po uzoru na one televizijske. Anketirani nastavnik dodaje da prezentacije najčešće učenici sami osmišljavaju u vidu projekta koji se brojčano ocenjuje. U radu, u nastavi 
se koriste i dodatni tekstovi kao dopuna postojećih pre svega radi upoznavanja sa kulturološkim činjenicama.

Vannastavni imput uključuje one sadržaje kojima su ispitanici bili izloženi izvan nastavnog okruženja. Sprovedeni upitnik za učenike daje uvid u ovaj deo podataka.

Obradom upitnika za učenike saznaje se da pri učenju engleskog jezika svi učenici petog razreda koriste udžbenik, video i TV zapise (filmove, serije, klipove) $65.1 \%$, dodatni materijal koji im donosi predmetni nastavnik (30.2\%), rečnik (32.6\%), pisma i razglednice $(4.7 \%)$, autentične materijale (brošure, reklame, meni...) 16.3\%, audio cd (34.9\%), kompjuter/cd rom (41.9\%), časopise, novine, knjige i stripove $(37.2 \%)$, poeziju, priče i bajke (16.3\%), pesme i recitacije (34.9\%), igrice $(58.1 \%)$.

Imajući u vidu gore navedene podatke i detaljnijim sagledavanjem pojedinačnih stavki upitnika za nastavnika i učenike došlo se do zaključka da je 39.5\% ispitanika petog razreda u velikoj meri izloženo engleskom jeziku, a njih $60.5 \%$ u manjoj.

\subsubsection{Analiza testova nivoa znanja za učenike petog razreda}

Podaci vezani za nivo znanja su utvrđeni prikupljanjem ocena ispitanika, izvođenjem srednje prosečne ocene kao i analizom testova za proveru nivoa znanja engleskog jezika .

Izvođenjem zaključne ocene iz engleskog jezika učenika petog razreda na polugodištu 2014/2015. uočava se da je njih $86 \%$ postiglo odličan i vrlodobar uspeh, dok je 14\% postiglo dobar i dovoljan uspeh.

S druge strane, rezultati testiranja učenika iz engleskog jezika u drugom polugodištu školske 2014/2015. nedvosmisleno pokazuju da je 72\% učenika petog razreda postiglo odličan i vrlodobar uspeh, a njih $28 \%$ dobar i dovoljan.

$\mathrm{Na}$ osnovu gore navedenih podataka poređenjem uspeha učenika na testovima sa zaključnim ocenama sa polugodišta 2014/2015. i izvođenjem aritmetičke sredine primećuje se da 79\% ispitanika petog razreda pokazuje viši nivo znanja engleskog jezika (ocene 4 i 5), dok njih $21 \%$ pokazuje niži nivo iz engleskog jezika (ocene 2 i 3 ).

\subsection{Podela ispitanika na podgrupe}

Obrađeni upitnici i ankete su pružili celokupnu sliku vezanu za nivo znanja i količinu izloženosti engleskom jeziku ispitanika petog razreda i stoga omogućili dodatnu podelu ispitanika na podgrupe. U skladu sa ovim 
podacima, može se zaključiti da se u okviru anketiranih ispitanika petog razreda razlikuju sledeće podgrupe:

I Visok nivo znanja/ velika količina izloženosti

II Visok nivo znanja/ mala količina izloženosti

III Nizak nivo znanja/ mala količina izloženosti

$\mathrm{Na}$ osnovu dalje analize dobijenih podataka iz upitnika za učenike i testova nivoa znanja engleskog jezika nameće se zaključak da se 39\% ispitanika petog razreda (17 ispitanika) može svrstati u I podgrupu, 35\% ispitanika (15 učenika) u II, a 26\% ispitanika (11 ispitanika) u III podgrupu.

\subsection{Analiza rezultata testova pisane produkcije učenika petog razreda}

Kada je reč o rezultatima pisane produkcije na italijanskom jeziku učenika petog razreda pokazalo se da sve tri grupe (I grupa-Visok nivo znanja/ velika količina izloženosti; II grupa- Visok nivo znanja/ mala količina izloženosti i III grupa- Nizak nivo znanja/ mala količina izloženosti) prave leksičke i morfološke greške uslovljenje međujezičkim transferom iz engleskog jezika.

$\mathrm{Na}$ osnovu klasifikacije grešaka iz 2007. koju daje De Angelis (v. Poglavlje 4.1) kod učenika petog razreda izdvajaju se sledeći oblici međujezika: kalkovi, semantičke ekstenzije, kognati, hibridne tvorevine i slivenice, kao i pozajmljenice.

\subsubsection{Kalkovi}

U pogledu Kalkova, kod prve grupe učenika petog razreda (Visok nivo znanja/ velika količina izloženosti) zabeleženi su sledeći primeri:

1. Sport borsa (eng. sports beg; it. borsa sportiva);

2. Al uno place (eng. at one place; it. in un posto);

3. Tennis racheta (eng. tennis racket; it. racchetta da tennis).

Kod druge grupe (Visok nivo znanja/ mala količina izloženosti) i treće grupe učenika petog razreda (Nizak nivo znanja/ mala količina izloženosti) nisu zapaženi oblici kalkova.

U okviru ovog tipa konstrukcija međujezika jasno se uočava da se oblici kalkova javljaju samo kod prve grupe učenika petog razreda (Visok nivo znanja/ velika količina izloženosti) što dovodi do zaključka da nije dovoljan samo visok nivo znanja engleskog jezika da bi došlo do ovog tipa transfera, već je neophod- 
no da učenik u velikoj meri bude izložen prvom stranom jeziku. S obzirom na mali broj oblika ovog tipa međujezika dolazi se do zaključka da ovaj tip međujezičkih konstrukcija nije tipičan za uzrast u okviru koga je obavljeno istraživanje. Takođe, nameće se i zaključak da se možda ovaj tip oblika međujezika ne zasniva prvenstveno na uticaju prvog stranog jezika (Ringbom, 2001).

\subsubsection{Semantičke ekstenzije}

Ukoliko se pogledaju oblici Semantičkih ekstenzija, kod prve grupe učenika petog razreda (Visok nivo znanja/ velika količina izloženosti) nailazi se na primere neodgovarajuće lične zamenice u konstrukcijama sa glagolom piacere:

1. Io piace... (eng. I like; it. Mi piace) ili čak Lei non piacciono (eng. She doesn’t like; it. A lei non piacciono).

Kada je reč o Semantičkim ekstenzijama kod druge grupe učenika petog razreda (Visok nivo znanja/ mala količina izloženosti), zabeležen je samo jedan primer tj. greška koju je napravio jedan učenik:

2. Io sono undici (eng. I'm eleven years old; it. Io ho undici anni).

Kod treće grupe učenika petog razreda (Nizak nivo znanja/ mala količina izloženosti) nisu zapaženi oblici semantičkih ekstenzija.

Na osnovu gorenavedenih primera može se doći do zaključka da se ovaj oblik međujezika javlja kod grupe ispitanika koja poseduje visok nivo znanja prvo stranog jezika, dok količina izloženosti nije faktor od presudnog uticaja za pojavu ovog tipa transfera. Takođe, kao i u slučaju kalkova mali broj primera semantičkih ekstenzija upućuje na zaključak da se ovaj tip transfera ne zasniva prevashodno na uticaju prvog stranog jezika (v. Poglavlje 4.1).

\subsubsection{Kognati}

U pogledu Kognata kod prve grupe učenika petog razreda (Visok nivo znanja/ velika količina izloženosti) nailazi se na sledeće primere:

1. I miei parenti sono Maria e Milan; Mio pade e mia madre sono i miei parenti; (eng. parents-u značenju roditelji, umesto it. genitori- dok parenti na it. označavaju rodjake);

2. In inverno nevica e fa molto caldo (eng. cold-znači hladno, umesto it. freddodok pridev caldo na it. znači toplo); 
3. Babbo Natale porta i presenti ai bambini; prezenti (eng. present- znači poklon, umesto it. regali-dok reč present na it. znači prisutan);

4. Il dono (učenik je hteo da kaže krofna eng. donut, dok reč dono na it. znači poklon);

5. Io resto in casa (eng. to rest- znači odmoriti se, umesto it. mi riposo- dok reč restare na it. znači ostati);

6. $\quad$ Classe di italiano (eng. class- znači čas, umesto it. lezione-dok reč classe znači razred).

Kada je reč o Kognatima kod druge grupe učenika petog razreda (Visok nivo znanja/ mala količina izloženosti), beleže se sledeći primeri:

7. Presento; Babbo Natale porta i presenti ai bambini (eng. present umesto it. regalo);

8. In inverno nevica e fa molto caldo (eng. cold-znači hladno, umesto it. freddodok pridev caldo na it. znači toplo).

Kod treće grupe učenika petog razreda (Nizak nivo znanja/ mala količina izloženosti) nisu zapaženi oblici kognata.

Kao što se može primetiti, kognati kao tip konstrukcija međujezika se javljaju kod prve dve grupe ispitanika (Visok nivo znanja/ velika količina izloženosti i Visok nivo znanja/ mala količina izloženosti) što navodi na zaključak slično kao kod semantičkih ekstenzija da je visok nivo znanja prvog stranog jezika neophodan za pojavu ovog tipa transfera. Ovo zapažanje nije u potpunosti u skladu sa tvrdnjama Ringboma (2001) koji zastupa mišljenje da kognati kao tip transfera forme mogu nastati nezavisno od nivoa znanja jezika (v. Poglavlje 4.1).

\subsubsection{Hibridne tvorevine i slivenice}

Kod prve grupe učenika petog razreda (Visok nivo znanja/ velika količina izloženosti) nailazi se na mnoštvo primera oblika Hibridnih tvorevina i slivenica, a među njima najviše onih reči kod kojih se na reč iz engleskog jezika dodaje morfema za građenje muškog ili ženskog oblika, kao i oblika množine reči u italijanskom jeziku, zatim odgovarajućeg lica prezenta kao i reči napisanih pod uticajem fonetskih pravila engleskog jezika :

1. Ci sono libri e guitaro (eng. guitar; it. chitarra);

2. Ci sono molti libri, computero e radio (eng. computer; it. computer);

3. Il letto è tra l'armadio e il lampo (eng. lamp; it. lampada); 
4. A sinistra sono magazini (eng. magazine; it. riviste);

5. Sponga ; spongo ; (eng. sponge; it. spugna);

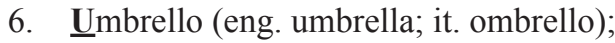

7. Syropo (eng. syrop; it. sciroppo);

8. Palaca ; palaco; (eng. palace; it. palazzo);

9. Collectia; colectione; (eng. collection; it. collezione);

10. Scrivo il testo (eng. test; it. test);

11. Ospidal ili čak ospidale (eng. hospital, it. ospedale);

12. Corridoro (eng. corridor; it. corridoio);

13. Italiano fooda (eng. food; it. cibo);

14. Io vado tu guardare i negozi/ Io vado tu scuola di disegno (eng. to; it. a);

15. Loro tokano (eng. to talk; it. parlano);

16. Schuola (eng. school; it. scuola);

17. Geographia (eng. Geography; it. geografia).

U pogledu Hibridnih tvorevina i slivenica kod druge grupe učenika petog razreda (Visok nivo znanja/ mala količina izloženosti), beleži se dosta primera reči engleskog jezika kod kojih se dodaje italijanska morfema za građenje oblika muškog ili ženskog roda; zatim reči napisanih pod uticajem fonetskih pravila engleskog jezika:

18. Computero (eng. computer; it. computer);

19. Lampo (eng. lamp; it. lampada);

20. Io ho tou fratelli (eng. two; it. due);

21. Restaurante (eng. restaurant; it. ristorante);

22. Ballo è di fronte a bed (eng. ball; it. palla, pallone);

23. Septembro ili septembre (eng. september; it. settembre);

24. Scholla ili čak schuola (eng. school; it. scuola);

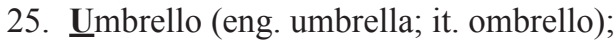

26. Cantante perfecto (eng. perfect; it. perfetto);

27. Apartmento (eng. apartment; it. appartamento);

28. Colectione (eng. collection; it. collezione);

29. Hospedale (eng. hospital; it. ospedale);

30. Doro (eng. door; it. porta);

31. Lei è smarta (eng. smart; it. intelligente);

32. Thre (eng. three; it. tre).

Kada je reč o Hibridnim tvorevinama i slivenicama kod treće grupe učenika petog razreda (Nizak nivo znanja/ mala količina izloženosti), uočavaju se primeri kod kojih se dodaje italijanska morfema za građenje oblika muškog ili ženskog roda; zatim reči napisanih pod uticajem fonetskih pravila engleskog jezika. Sa tim u vezi zabeleženi su sledeći primeri: 
33. Lampo (eng. lamp; it. lampada);

34. Beggo (eng. beg; it. borsa);

35. Computero ili čak computere (eng. computer; it. computer);

36. Commodo (eng. commode; it. comò);

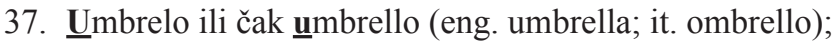

38. Vollibolle (eng. volleyball; it. pallavolo);

39. Schula ili čak scholo (eng. school; it. scuola);

40. A ungosto (eng. august; it. agosto);

41. Choccolato (eng. chocolate; it. cioccolato);

42. Pencilo (eng. pencil; it. penna).

Mnoštvo primera hibridnih tvorevina i slivenica karakaterističnih za sve tri grupe ispitanika jasno upućuje na zaključak da ovaj tip konstrukcija međujezika nastaje pod uticajem prvog stranog jezika, kao i da ovaj oblik transfera nastaje nezavisno od nivoa znanja i količine izloženosti engleskom jeziku (v. Poglavlje 4.1). S druge strane, budući da se najveći broj oblika ovog tipa međujezičkog transfera može uočiti kod prve grupe ispitanika (Visok nivo znanja/ velika količina izloženosti) može se zaključiti da nivo znanja i količina izloženosti utiču na sposobnost učenika da koriste sopstveno znanje engleskog jezika prilikom građenja hibridnih tvorevina i slivenica.

\subsubsection{Pozajmljenice}

I među oblicima Pozajmljenica kod prve grupe učenika petog razreda (Visok nivo znanja/ velika količina izloženosti) nailazi se na dosta primera, naročito na upotrebu odgovarajućih predloga karakterističnih za engleski jezik ili pak reči napisanih u originalu kao u engleskom jeziku. Zanimljiva je i upotreba lične zamenice I, nastavka 's za građenje saksonskog genitiva kao i upotreba trećeg lica jednine glagola to be:

1. Stefan è on letto (eng. on znači na; it. sul);

2. I libri sono on scrivania (eng. on; it. sulla);

3. Noi andiamo to cinema (eng. to the cinema; it. al cinema);

4. Festeggio on ventidue gennaio (eng. on the 22 of january; it. il 22 gennaio);

5. Umbrella (engl. umbrella; it. ombrello);

6. Mangio sempre il sandwich (eng. sandwich; it. panino);

7. Design (eng. design, it. disegno);

8. From Belgrado (eng. from; it. di);

9. Voglio to guardare/ Decidono to entrano/Quando voglio to compro; (eng. to; it. voglio guardare/ decidono di entrare/ voglio comprare);

10. Il biglietto for cinema (eng. for; it. per il); 
11. Upotreba engleske lične zamenice I (it. io): $\underline{\mathbf{I}}$ mi alzo/ $\underline{\mathbf{I}}$ gioco ai videogiochi/

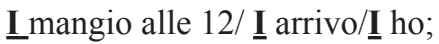

12. Lui's zaino (eng. 's -nastavak za saksonski genitiv umesto it. il suo zaino),

13. Seguo lo sport on TV (eng. on; it. alla);

14. Il film is tradizionale (eng. is- od glagola to be; it. è);

15. Una volta at mese (eng. at; it. al);

16. Io parlo on inglese e italiano (eng. on; it. in);

17. Palla è di front of letto (eng. in front of; it. di fronte a);

18. La capital dell'Italia (eng. capital, it. capitale).

Kada je reč o Pozajmljenicama kod druge grupe učenika petog razreda (Visok nivo znanja/ mala količina izloženosti), beleže se primeri upotrebe engleskih reči napisanih u originalu. Naročito je česta upotreba engleskih predloga. Zanimljiva je i upotreba lične zamenice I i Me, kao i zamenice u kombinaciji sa trećem licem jednine glagola to be: It's. Sa tim u vezi izdvajaju se sledeće primeri:

19. Stefan è in letto (eng. Stefan is in bed; it. Stefano è sul letto);

20. Stefan è on the letto (čak i bez člana on letto; it. sul letto); zatim On letto sono libri; On scrivania/ Io gioco on computer (it. sul letto/sulla scrivania/al computer);

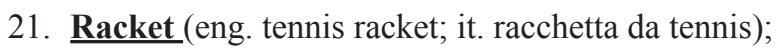

22. Loro vanno to mio compleanno/ Io vado to cinema; Io regalo to nonni/ io vado to nonno e Io regalo libri to altri/ Vai to Via Resavska (eng. to; it. pred$\log$ a u kombinaciji sa odgovarajućim oblikom određenog člana ili čak pred$\log$ in u primeru in Via);

23. In camera è bed ili Accanto a bed (it. letto);

24. Mio compleanno is of 5 september (it. è il 5 settembre);

25. Sandwich (it. panino);

26. Sopra i letto ci sono molti posters (eng. posters; it. manifesti);

27. Ski (it. sci);

28. Me non vado allo stadio (it. io);

29. It's divertente (it. è);

30. Upotreba engleske lične zamenice I (it. io): $\underline{\mathbf{I}}$ dormo/ $\underline{\mathbf{I}}$ guardo la TV/ $\underline{\mathbf{I}}$ ho 12 anni.

U pogledu Pozajmljenica kod treće grupe učenika petog razreda (Nizak nivo znanja/ mala količina izloženosti), takođe se nailazi na primere reči iz engleskog jezika napisanih u originalu, kao i na upotrebu par engleskih predloga i lične zamenice they: 
31. Stefan è on letto (eng. on; it. sul);

32. Io vado to Petar Petrović scuola (eng. to; it. alla scuola);

33. Ball (eng. ball; it. palla, pallone);

34. Posters/poster (eng. poster; it. manifesto/manifesti);

35. Tomato (eng. tomato; it. pomodoro);

36. Ii bevo milk (eng. milk; it. latte);

37. In questo photo (eng. photo; it. foto);

38. They vivono (eng. They; it. loro);

39. Io fai ski (eng.ski; it. sci);

40. Preferiti subject (eng. subjects; it. materie).

Kao što se može zapaziti iz prethodnih primera, pozajmljenice kao tip međujezičkog transfera se javljaju kod sve tri grupe ispitanika (Visok nivo znanja/ velika količina izloženosti, Visok nivo znanja/ mala količina izloženosti i Nizak nivo znanja/ mala količina izloženosti) što navodi na sličan zaključak kao u pogledu hibridnih tvorevina i slivenica. U skladu sa Ringbomovom tvrdnjom (v. Poglavlje 4.1) uočava se da i ovaj tip kontrukcija međujezika nastaje pod uticajem prvog stranog jezika nezavisno od nivoa znanja i količine izloženosti. S obzirom da je kod ovog tipa transfera reč o slučajevima potpune zamene reči italijanskog jezika rečju iz engleskog zaključuje se da ovaj oblik međujezika nastaje kao posledica nedostatka vokabulara drugog stranog jezika što je karakteristično za grupu ispitanika petog razreda i prvu godinu učenja italijanskog jezika kada se ovaj tip leksičkog transfera koristi kao kompenzaciona strategija kako se ne bi odustalo od komunikacije.

\subsubsection{Uporedna analiza rezultata testova pisane produkcije učenika petog razreda}

Ukoliko se uporede rezultati učenika petog razreda, uočava se da je najveći broj međujezičkih kontrukcija nastalih pod uticajem engleskog jezika prisutan kod prve grupe učenika (Visok nivo znanja/ velika količina izloženosti). Ovi rezultati su u skladu sa pretpostavkom da engleski jezik ima veći uticaj na polju leksike i morfologije onih ispitanika koji poseduju viši nivo znanja engleskog jezika i koji su u većoj meri bili njemu izloženi (v. Poglavlje 5.2). Razlog za ovakav rezultat svakako leži u višem jezičkom nivou znanja engleskog jezika kao i činjenici da je ova grupa ispitanika najviše bila izložena engleskom jeziku. Ukoliko se pogledaju rezultati treće grupe učenika (Nizak nivo znanja/ mala količina izloženosti) takođe 
se dolazi do zaključka da se i kod ove grupe ispitanika mogu uočiti oblici međujezičkog transfera, no doduše u mnogo manjem obimu od prve dve grupe (Tabela 1).

Međujezički uticaj iz engleskog jezika -5 . razred

\begin{tabular}{|c|c|c|c|}
\hline & \multicolumn{2}{|c|}{ Visok nivo znanja engleskog jezika } & $\begin{array}{l}\text { Nizak nivo znanja } \\
\text { engleskog jezika }\end{array}$ \\
\hline & $\begin{array}{l}\text { Velika količina } \\
\text { izloženosti } \\
\text { engleskom jeziku }\end{array}$ & $\begin{array}{l}\text { Mala količina } \\
\text { izloženosti } \\
\text { engleskom jeziku }\end{array}$ & $\begin{array}{c}\text { Mala količina } \\
\text { izloženosti } \\
\text { engleskom jeziku }\end{array}$ \\
\hline & Broj učenika: 17 & Broj učenika: 15 & Broj učenika: 11 \\
\hline Kalkovi & 3 & 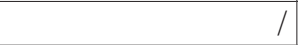 & 1 \\
\hline $\begin{array}{l}\text { Semantičke } \\
\text { ekstenzije }\end{array}$ & 2 & 1 & I \\
\hline Kognati & 14 & 6 & 1 \\
\hline $\begin{array}{l}\text { Hibridne tvorevine } \\
\text { i slivenice }\end{array}$ & 32 & 22 & 14 \\
\hline Pozajmljenice & 26 & 25 & 11 \\
\hline Ukupno & 77 & 54 & 25 \\
\hline
\end{tabular}

Tabela 1: Oblici međujezika učenika petog razreda.

Budući da je najviše oblika međujezika zabeleženo kod ispitanika koji poseduju visok nivo znanja i koji su u velikoj meri bili izloženi engleskom jeziku, zaključuje se da varijable nivo znanja i količina izloženosti utiču na pojavu međujezičkog transfera engleskog u produkciji italijanskog jezika. Takođe, prisustvo međujezičkih konstrukcija kod ispitanika koji poseduju nizak nivo znanja i u manjoj meri su bili izloženi engleskom jeziku, upućuje na zaključak da varijable nivo znanja i izloženost nisu jedine koje utiču na pojavu međujezičkog transfera na ovom uzrastu.

\section{Zaključak}

$\mathrm{Na}$ osnovu rezultata celokupnog testiranja moguće je zaključiti da dve vrste međujezičkog transfera dominiraju prilikom građenja ciljnih reči u pisanoj produkciji na italijanskom jeziku učenika petog razreda (v. Poglavlja 4.1. i 4.2): 
1. Leksički međujezički transfer koji se odnosi na upotrebu cele neciljne reči (iz engleskog jezika) u produkciji ciljne reči (u italijanskom jeziku) i

2. Morfološki međujezički transfer koji se odnosi na produkciju oblika međujezika kod koga se slobodna ili vezana morfema iz engleskog jezika kombinuje sa slobodnom ili vezanom morfemom iz italijanskog jezika u cilju nastajanja reči slične onoj u ciljnom jeziku.

Leksički i morfološki transfer u istraživanju se u najvećoj meri odnose dakle na upotrebu neciljne reči ili morfeme u produkciji ciljnog jezika.

Prema Ringbomu (1986:158), iako se transfer značenja vezuje za maternji jezik, kao tip uticaja koji zahteva , znatnu fluentnost i automatizaciju jezika iz kog transfer potiče", on takođe kako Ringbom zapaža može da nastane iz prvog stranog jezika ukoliko je nivo znanja tog jezika dovoljno visok (v. Poglavlje 4.1). U goreopisanom istraživanju, budući da su oblici transfera značenja (kalkovi i semantičke ekstenzije) prisutni kod prve i druge grupe ispitanika petog razreda (Visok nivo znanja/ velika količina izloženosti i Visok nivo znanja/ mala količina izloženosti) to donekle potvrđuje ovo Ringbomovo zapažanje. U tom smislu, u situacijama kada imamo učenika sa visokim znanjem prvog stranog jezika koji je u velikoj meri tom istom jeziku izložen, očekujemo da sretnemo ne samo oblike transfera forme već i greške koje se tiču kalkova i semantičkih ekstenzija (Ringbom, 2001). To navodi na zaključak da transfer ne utiče samo na oblik jezika već i na semantički obrazac.

Detaljnom analizom rezultata istraživanja može se zaključiti da se na ovom uzrastu (peti razred) javljaju u velikoj meri oblici transfera forme (pozajmljenice, hibridne tvorevine i slivenice, kognati), dok se oblici transfera značenja (kalkovi i semantičke ekstenzije) retko ili skoro uopšte i ne sreću (v. Tabelu 1). Samim tim da se zaključiti da se leksički i morfološki transfer u najvećoj meri javlja kao transfer oblika. Ovo je u potpunosti u skladu sa onim što i sam Ringbom (2001) zaključuje kada navodi da gde god imamo uticaj prvog stranog na drugi strani jezik to će biti transfer celog oblika reči prvog stranog jezika, ili u potpunosti ili u nešto izmenjenom obliku (Ringbom, 2001: 68).

$\mathrm{Na}$ osnovu celokupne analize rezultata istraživanja zaključuje se da jedan od razloga zašto učenici pribegavaju oblicima reči iz engleskog jezika svakako leži u činjenici da pokušavaju da premoste jaz u znanju nastao usled nedovoljnog poznavanja italijanskog jezika. Stoga učenici u tom 
smislu koriste leksički transfer kao kompenzacionu strategiju (Ringbom, 1986, Agustín Llach, M.P, 2010). Sa druge strane, moguće da je učenici na tom uzrastu reč iz engleskog jezika doživljavaju kao fonološki blisku reči u italijanskom jeziku pa se upravo iz tog razloga odlučuju za reč iz prvog stranog jezika. S tim u vezi, rezultati istraživanja pokazuju da se transfer oblika ne odnosi isključivo i samo na celu reč, kao što je to slučaj sa pozajmljenicama već u slučaju hibridnih tvorevina i slivenica on uključuje i vezane morfeme (Murphy, 2003; Hammaberg, 2001; De Angelis \& Selinker, 2001). Detaljnijom analizom navedenih primera hibridnih tvorevina i slivenica jasno uočava se način nastanka ovih oblika međujezika. Zaključuje se da je mahom reč o primerima gde osnova reči potiče iz engleskog, a vezana morfema iz italijanskog jezika (v. Poglavlje 5.5.1.4).

Rezultati istraživanja ukazuju na činjenicu da je učenikov nivo znanja prvog stranog jezika svakako faktor od vitalnog značaja što je u skladu sa pretpostavkom istraživanja (v. Poglavlje 5.2). U tom smislu nameće se zaključak da će neko sa visokim nivoom znanja prvog stranog jezika radije koristiti strategije koje se baziraju na njegovom znanju prvog stranog jezika od onih koje se oslanjaju na znanje maternjeg jezika. U kom obimu i u kom kontekstu se aktivira znanje prvog stranog jezika kod učenika koji poseduje visok nivo znanja prvog stranog jezika je pitanje koje zahteva svakako dalja istraživanja.

Na kraju ovog poglavlja može se zaključiti da se transfer iz prvog stranog jezika u produkciji na drugom stranom jeziku kod učenika u početnoj nastavi italijanskog kao stranog pre svega ogleda na polju leksike. Prikazani rezultati upućuju na zaključak da se transfer uglavnom javlja kao rezultat međujezičkog podudaranja sličnog pojedinačnog oblika reči i da je uslovljen faktorima nivo znanja i količina izloženosti tj. veća količina izloženosti i viši nivo znanja vode do većeg međujezičkog transfera.

\section{Literatura.}

Agustín Llach, M. P. (2010). An Overview of Variables Affecting Lexical Transfer in Writing: A Review Study. International Journal of Linguistics, 2, 1-17.

De Angelis, G. and Selinker, L. (2001). Interlanguage transfer and competing linguistic systems in the multilingual mind. In Cenoz, Jasone, B. Hufeisen and Ulrike Jessner (eds.), Cross-linguistic influence in third language acquisition: Psycholinguistic perspectives (pp. 42-58). Clevedon: Multilingual Matters. 
De Angelis, G. (2007). Third or Additional Language Acquisition. Clevedon: Multilingual Matters.

Dewaele, J. (1998). Lexical Inventions: French Interlanguage as L2 versus L3. Applied Linguistics, 19, 471-490.

Fuller, J. (1999). Between three languages: Composite structure in interlanguage. Applied Linguistics, 20, 534-561.

Hammarberg, B. (2001). Roles of L1 and L2 in L3 production and acquisition. In J. Cenoz, B. Hufeisen and U. Jessner (eds), Cross-linguistic Influence in Third Language Acquisition: Psycholinguistic Perspectives (pp. 21- 41). Clevedon: Multilingual Matters.

Manchón Ruiz, R. (2001). Un acercamiento psicolingüístico al fenómeno de la transferencia en el aprendizaje y uso de segundas lenguas. In V. Salazar, $\& \mathrm{~S}$. Pastor (eds.), Tendencias y líneas de investigación en adquisición de segundas lenguas (pp. 39-71). Anexo 1: ELUA Estudios de Lingüística de la Universidad de Alicante.

Murphy, S. (2003). Second Language Transfer During Third Language Acquisition. TESOL and Applied Linguistics, 3, 1-21.

Odlin, T. (1989). Language Transfer. Cross-linguistic Influence in Language Learning. Cambridge: Cambridge University Press.

Ortega, M. (2008). Cross-linguistic influence in multilingual language acquisition: The role of L1 and non-native languages in English and Catalan oral production. Íkala, revista de lenguaje y cultura, 13, 121- 142.

Poulisse, N. and Bongaerts, T. (1994). First language use in second language production. Applied Linguistics, 15, 36-57.

Ringbom, H. (1986). Crosslinguistic influence and the foreign language learning process. In M. Sharwood Smith \& E. Kellerman (eds.), Crosslinguistic influence in second language acquisition (pp. 150-162). Oxford, UK: Pergamon Press.

Ringbom, H. (1987). The Role of the First Language in Foreign Language Learning. Clevedon: Multilingual Matters.

Ringbom, H. (2001). Lexical transfer in L3-production. In J. Cenoz, B. Hufeisen and U. Jessner (eds), Cross-linguistic Influence in Third Language Acquisition: Psycholinguistic Perspectives. (pp. 59-68). Clevedon: Multilingual Matters.

Tremblay, M.-C. (2006). Cross-Linguistic influence in Third Language Acquisition: The role of L2 Proficiency and L2 Exposure. Cahiers Linguistiques d'Ottawa, 34, 109-119.

Weinreich, U. (1953). Languages in Contact. New York: Linguistic circle of New York. 
LEKSIČKI I MORFOLOŠKI TRANSFER U POČETNOJ NASTAVI ITALIJANSKOG ...

Snežana Z. Detar Jevđović

\section{LEXICAL AND MORPHOLOGICAL TRANSFER AT THE BEGINNER'S LEVEL OF TEACHING ITALIAN AS L2}

\section{Summary}

In addition to theoretical framework, paper encompasses the analysis of the results with regard to the study examining how the language proficiency and the amount of exposure to the English language as the first foreign language influence the written production of lexis and morphology of Italian as the second foreign language with regard to students in initial Italian language teaching as foreign language. The fifth grade pupils of the primary school "Petar Petrović Njegoš" studying the English language from the first grade and the Italian language from the fifth grade have been tested. Obtained data have been processed using the methods of quantitative and qualitative analysis. The major objective of the paper is to analyse critically lexical and morphological characteristics with regard to the interlanguage of the fifth grade pupils. The results of the research have shown that two types of cross-linguistic influence are dominant in the construction of target words in written production in the Italian language of fifth-grade students: 1. a lexical cross-linguistic influence that refers to the use of a non-target word (from English) in the production of the target word (in Italian) and 2. a morphological cross-linguistic influence that relates to the production of forms of interlanguage in which free or bound morpheme from English language is combined with a free or bound morpheme from the Italian language in order to create a word similar to that in the target language.

Key words: cross-linguistic influence, language proficiency, amount of exposure, lexis, morphology, English and Italian language, first foreign language, second foreign language. 